\title{
Deservingness for "Family $500+$ " Benefit in Poland: Qualitative Study of Internet Debates
}

\author{
Piotr Michoń ${ }^{1}$ (D)
}

Accepted: 19 February 2021 / Published online: 2 March 2021

(C) The Author(s) 2021

\begin{abstract}
The need for qualitative research of deservingness perception is strongly emphasised in the literature. This article studies the perception of deservingness for a "Family $500+"$ cash benefit in Poland. For the first time, data from online forums was used in the studies of deservingness and welfare attitudes. It allowed to avoid numerous limitations associated with social surveys. The qualitative analysis showed how participants of Internet debates perceive the criteria of deservingness: control, attitude, reciprocity, identity, need, and what are the relations between the criteria. The impurity of all deservingness criteria was indicated and a new criterion "adequacy" was proposed. Moreover due to the fact that the study concerned a concrete, non-abstract family cash benefit addressed the relationship between the perceived deservingness of children and their parents was pointed out. The vast majority of posts on Internet forums referred to deservingness of parents, not children. This is particularly evident in relation to the criteria of control and reciprocity. Presenting the hypothesis of jealousy and scapegoat strategy, the article also shows the direction of future research on deservingness.
\end{abstract}

Keywords Deservingness · Internet forum · Family benefit · Family policy · Family $500+\cdot$ Welfare state attitudes · Qualitative study · Poland

\section{Introduction}

The notion of deservingness represents a core aspect in discussion on social justice, relative depravation or sustainability and legitimacy of welfare policy. Welfare state is under pressure from political, demographic, social and economic changes (e.g. Greer, 2016). Therefore, the need to provide social support for the welfare state is gaining on importance. While there is a fairly common consensus that individuals should receive what they deserve (Kagan, 2012) people are likely to accept and support welfare policy if the beneficiaries are perceived as deserving.

There is a broad literature studying the perception of deservingness of welfare beneficiaries (Aarøe \& Petersen, 2014; Gielens et al., 2019; Jeene et al., 2013; Petersen, 2011;

Piotr Michoń

piotr.michon@ue.poznan.pl

1 Poznań University of Economics and Business, al. Niepodległości 10, 61-875 Poznań, Poland 
Reeskens \& van der Meer, 2019; van Oorschot, 2006 etc.). Most of the previous studies on deservingness perception are of quantitative nature; rely on a representative population surveys and strive to answer how societies perceive the extent to which different subgroups of citizens are deemed worthy or unworthy of receiving help. Oorschot and Roosma (2015, p. 25) noticed: 'a problem in present day deservingness research is that deservingness criteria are pre-determined by researchers, deduced from existing literature and theories, and that their importance is assessed with quantitative techniques of data gathering and analysis.' The need for a qualitative approach is increasingly pointed out, but its' use is very limited (with exceptions of: Laenen et al., 2019; Nielsen et al., 2020). It seems that further progress of deservingness studies might be at risk when the analysis limits to quantitative approach. Therefore, the first aim of the study is to use qualitative approach in order to answer the questions asked by Laenen et al. (2019): 'Do people really use (all) CARIN (control, attitude, reciprocity, identity, need) criteria (maybe they also use others) when assessing deservingness? And how exactly do people understand these criteria?'.

Numerous surveys use fictional solidarity situation in order to evaluate deservingness of various groups of people (Olesen, 2019). The questions asked in the survey studies are intended to prompt the respondent to rational but also artificial estimates that are not necessarily found in real-life settings. However, individuals are constantly responding to the people and the environment around them (Hughes, 1998). That is why in this article I applied a research method that was not previously used; internet forums content analysis. The Internet forums posts reflect the real, and thanks to anonymity also unfettered interaction between people. Thus I seek to contribute to the debate on deservingness by demonstrating the value of the internet forums studies.

Part of previous studies served to determine which of the deservingness criteria are more important: (for example: reciprocity, control and identity when evaluating the deservingness of immigrants in the Netherlands) (Reeskens \& van der Meer, 2019), others indicate which groups of beneficiaries are more or less deserving (e.g. older people are considered as more deserving of welfare distribution than are unemployed people) (van Oorschot, 2006). Large number of previous studies focused on specific groups e.g.: immigrants (Nielsen et al., 2020; Reeskens \& van der Meer, 2019); disability pensioners (Jeene et al., 2013), unemployed (Jeene \& Van Oorschot, 2014). This article is about deservingness for family cash benefit ("Family 500+" program), which leads to a different operationalisation. The beneficiaries of the benefit are not always perceived as the same people whose deservingness is assessed. Money goes to parents, but children are often perceived as the main beneficiaries. This discrepancy leads to questions regarding individual criteria for assessing deservingness, e.g.: 'Whose needs, parents or children are taken into account when assessing deservingness?', 'How is reciprocity of parents and children understood?', 'Whose control over the situation is taken into account?'.

While it is often assumed that deservingness criteria are common for all people (Aarøe \& Petersen, 2014) public support for welfare state and welfare spending in general, and welfare benefits in particular, vary widely throughout the countries (Alesina \& Angeletos, 2005; Alesina et al., 2001; Lahusen et al., 2018; Larsen, 2008; Rothstein, 1998). The article provides a deep reflection on Poland-for many reasons an important case. Firstly, little is known about the perception of deservingness in Poland. Secondly, Poland is a country undergoing a process of significant political and economic changes that have undoubtedly influenced the approach of Poles to the welfare state and its beneficiaries. The third reason is the introduction of the "Family 500+"- the largest benefit program ever introduced in Poland. While most of the previous studies which used the popular CARIN criteria for evaluating of general deservingness for support (van Oorschot, 2006) were based 
on abstract (also vintages) situation or discussed deservingness more generally, this study deals with an existing, well-recognised benefit.

In this paper I contribute to the development of studies on deservingness for welfare in both theoretical and methodological sense. The purpose of the article is: (1) to deepen knowledge about the way people perceive deservingness criteria (CARIN) and about the relationships between the criteria; (2) using for the first time, internet forums to study attitudes towards the welfare state; (3) examination of deservingness in relation to a specific and commonly discussed cash benefit paid in Poland. Additionally in the study (4) I propose a new criterion for assessing deservingness: adequacy. What is new is also the analysis of deservingness for (5) a family cash benefit. The beneficiaries are families with children, which leads to complex situation for deservingness assessment. I also seek to contribute by (6) indicating the future directions of studies.

This study of Internet discussions on "Family 500+" programme in Poland is, according to the author's knowledge, the first analysis of Internet forums devoted to the welfare state programmes. The study shows how people understand criteria of deservingness, displays relations between them, reveals the complexity of deservingness attitudes and proposes a new criterion of adequacy.

\section{2 "Family $500+$ "}

The "Family 500+" ("Rodzina 500+") ${ }^{1}$ program was launched in April 2016. Between April 2016 and June 2019 families received a relatively high (one fourth of minimum wage monthly) cash benefit in the amount of PLN 500 (about €120) for the second and each subsequent child under the age of 18 . For families with low incomes, the allowance was also paid for the first child in the family. In July 2019, the income criterion was abolished and since then the allowance is universal: it is paid for every child in the family. This article analyses Internet forums until June 30, 2019 so the cash benefit for the first child in the family was income tested.

The program covered (February 2019): 2.38 million families and 3.62 million children (52 percent of all children under 18 in Poland) (MRPiPS, 2019). ${ }^{2}$ The government's goals of the "Rodzina 500+" program are (MRPiPS, 2019): increasing the number of births; reduction of family poverty; and improving the quality of human capital of children. In previous studies the researchers analysed the objectives of the program, political consequences and impact on the quality of new generations of Poles, reproductive behaviour, women's labour market activity, poverty and social deprivation (for review see: Michon, 2020). For now, however, there is a lack of research of the perception of deservingness.

The possibilities of attitudes analysis partly result from the widespread knowledge of the program in Polish society. Since the announcement of the first project of the program, it was widely discussed. Even before it was introduced almost all adult Poles heard about the program (98\%) and the vast majority (79\%) knew the rules for granting the benefit (CBOS 2016). This is probably due to the amount of the benefit, easy to understand rules for its granting, extensive media coverage and the fact that many families are entitled.

\footnotetext{
1 In order to write about the programme "Family 500+" (and the cited Internet users) I use interchangeable the terms: "500+", "500 plus" or "Family $500+$ ".

2 Data from the end of February 2019 show that nearly PLN 67 billion has been delivered to families over almost 3 years (MRPiPS 2019).
} 


\section{Method and Data}

One of the main problems with survey studies is that the act of measurement can itself influence attitude for example by an item on a questionnaire (Kalton \& Schuman, 1982), environment or the researcher (e.g."self-presentation bias") (Arkin et al., 1980). If respondents are aware their answers are being monitored, this might stimulate them, to react in a way they find to be desirable ('social desirability bias'). In order to limit the negative effects, one should find a method, which guarantees anonymity, and does not force the respondent to express an opinion. What is needed are voluntary study participants who have their opinions and want to express them. These two requirements are met by online discussions studied in the paper.

Online discussions (ODs) provide natural data with few social constraints (Holtz et al., 2012). They gather geographically dispersed people who are interested in an issue, have their opinion and want to share it with others. ODs provide: self-initiated views with no time, length, or behavioural constrains. The anonymity of online discussions is conducive for their participants to be more forthright than they might be in surveys, focus groups or in-person interviews. Internet allows the presentation of a variety of, sometimes unpopular or politically incorrect, opinions which participants might not have expressed in the situation of direct contact with the researcher or other study participants. Anonymity gives a person the opportunity to express an opinion, which due to their position or social role a person cannot express (e.g. a mother who admits that she is bored playing with the child). For this reason, they can be seen as an extraordinary source for researchers analysing naturally emerging discourses. In the case of internet forums created and operating without the researcher's participation, numerous barriers limiting engagement in discussion are eliminated, thus shy, less dominant people may have a lower tendency to comply with dominant people. Moreover ODs have numerous advantages: almost unlimited amount of material for analysis, low cost of data acquisition, lack of research interfering and hence no impact on expression of thoughts, growing number of Internet users etc.. All these make Internet forums to provide text material for many kinds of social scientific analysis (Holtz et al., 2012; Im \& Chee, 2006; Shanks et al., 2014). The potential of online discussion has been used so far to study for example: tax issues of Uber drivers (Ring \& Oei, 2016), male infertility (Beeder \& Samplaski, 2019), autism (Jordan \& Caldwell-Harris, 2012), self-reported depression (Hausner et al., 2008), warning signs for suicide (McSwain et al., 2012), financial investments (Tumarkin and Whitelaw 2001), addictions (Barratt 2011; Soussan and Kjellgren 2015), weight loss (Hwang et al., 2007) and chronic diseases (Seale et al., 2010) etc.. This article represents the first attempt to analyse online forums to assess attitude towards welfare deservingness, that I know of its existence.

Anonymity of the Internet discussions is both their biggest advantage and disadvantage. First, anonymity can promote deindividuation effect—a tendency to express more extreme opinions than in face-to-face situation (Reicher et al., 1995). Secondly, since participants usually use fictitious nickname and their participation in the discussion is not regulated, thus only little sociodemographic information about the users is available (Holtz et al., 2012). A certain limitation is also the fact that only people with Internet access can participate in this type of study. However the range of Internet use is growing. Except the oldest people, Internet usage in Poland is completely common (thus the limitation of the study is the possible underrepresentation of older people) and almost one-third (32\%) of Internet users declare that in last month they posted a message on internet forums (CBOS 2019a). 
Searching for internet forums took place between January 2019 and June 2019. The first posts appeared on the analysed forums in November 2015-5 months before the program was launched, while the last one was published June 2019. All entries concerned the " $500+$ " program in which the first child benefit was means-tested.

In order to identify the forums for analysis I used google.pl to search for variety of words or combination of words (in Polish): (1) program's names used in media and everyday language: '500+', 'Family 500+', 'Program 500+', '500 plus'; (2) words such as: 'forum', 'discussion', 'debate', 'opinion', 'impact', 'effect', 'consequences', 'critique', 'evaluation'. I also used the questions like: 'how do you assess 500+', 'what are the consequences of $500+$ ?' etc.

\subsection{Selecting the Debates}

Initially, all forums and discussions that appeared among the hundred search results in the google.pl search engine were included in the analysis. Obviously, webpages containing discussions did not always appear in the search results, and searches for different words often provided the same results.

Under the next step, the debates were selected: Firstly, online discussions with at least 20 posts were included in the analysis. Secondly, the number of forum participants (identified by nicknames) had to be greater than 10 people. Thirdly, while studying attitudes, I ignored the forums that were of an informative nature (e.g. addressed legal issues related to the $500+$ program).

In this way, a list of 43 Internet debates that concerned issues related to the "Family $500+"$ was compiled (see the Appendix). The online discussions used in the analysis were initiated in various ways:

(1) by individual Internet users who have formulated a question or thesis themselves; many of the discussions appeared on portals that are used to create Internet debates. The initiators of the debates are the portal users who formulate a thesis or question to which other forum participants subsequently refer.

(2) articles that sparked a discussion; the articles that initiated the discussion were very different and published by local and national portals, newspapers, magazines and blogs. The topics of the articles were always related to $500+$ but in different ways. They concerned, among others: government goals, program costs, program beneficiaries' behaviours, beneficiaries' motivation, program effects, etc.

Forty three various online forums were analysed, with duration of discussions between 2 days and 36 months; number of posts between 10 and 5003 (posted within 8 months), and the collected material amounted for nearly 1500 text pages. In total, 10,915 posts were published in the selected forums from November 2015 to June 2019. However some of the posts were not analysed while they were not directly related to "Family 500+"; aimed to offend other forum participants or expressed opinions on political parties, government, etc.. In total, 67 percent of total posts were surveyed (7313). While users of many forums did not have their nicknames (they were registered as: 'anonymous', 'guest') I do know whether two or three nicknames are not used by the same person the number of forums participants is difficult to determine. However it is assumed to about 4.5-5.0 thousand people.

The studied ODs are very diverse. Some are very intense (a large number of posts in a short time) while others are not. Some of the forums last continuously for several months 
and others 2-3 days. In some forums, the discussion is multi-threaded and involves a lot of forum participants, in others the discussion is between just few people.

In the study the text on internet forums has been analysed with directed content analysis method. The posts were read, re-read, compared and discussed with the author's colleagues to develop a coding structure, which was then applied utilizing Atlas.di. The coding started with existing theory: the CARIN model of deservingness with deservingness criteria used as codes in the first step. In the second step, the relations between the examined deservingness criteria were coded and, as a result of the analysis in the first stage, the code was used to determine the new criterion of adequacy.

The starting point in my study were the CARIN deservingness criteria (van Oorschot, 2006):

1. control: poor people's control over their neediness, or their responsibility for it: the less control, the more deserving;

2. attitude: poor people's attitude towards support, or their docility or gratefulness: the more compliant, the more deserving;

3. reciprocity: the degree of reciprocation by the poor, or having earned support: the more reciprocation, the more deserving;

4. identity: the identity of the poor, i.e. their proximity to the rich or their 'pleasantness'; the closer to 'us', the more deserving;

5. need: the greater the level of need, the more deserving.

\subsection{The examples of coding}

"Pathological famiilies give birth to get 500+ pathologyEven if they are handicapped, they reproduce endlessly. And even when they are not... The child must be properly brought up to want to work. These children will be raised in families where they will be taught that they owe nothing to the society. They will never work." (fff).

- "Pathological families"—code: identity;

I assume that the authors of such negative statements do not consider themselves part of this group, thus they are distinguishing between we vs. they.

- "is giving birth to get $500+$ "- code: control;

This statement suggests that in fff's opinion people act intentionally and choose to have a child in order to receive the benefit. In other words they are in control of the situation.

- "These children will be raised in families where they will be taught that they owe nothing to the society. They will never work."-code: reciprocity;

While the beneficiaries are expected to reciprocate, the author of these statements does not believe that the children raised in the beneficiary families will be likely to work, pay taxes etc. in future.

"The problem is that the rich not only pay some taxes and they deserve it (the benefit-PM), but the 500+often ends up in their children's bank accounts. In the demanding families it is no longer so obvious, in most cases this money is wasted on stimulants and children continue to go and beg." (lazura).

- "money is wasted on stimulants and children continue to go and beg"—code "needs"; the needs of adults are satisfied, and using the money in order to satisfy the needs is not acceptable; 
- "the demanding families"—code: attitude;

The words (a person with a high level of the "sense of entitlement") put the described person in a very negative light. They (the families) demand the support, which does not arouse sympathy and represents an unacceptable attitude.

Coding was often difficult. Many of the posts could only be understood in the context of the entire discussion. They constituted a response to or referred to the statements of other forum participants. In some cases the post did not contain a word or phrase that clearly referred to the adopted coding system. However, they took on the meaning as a form of reaction to the statements of other participants, which allowed to code them.

\section{Control}

The criterion of control is based on the theory of attribution (Weiner, 1986): when interpreting the behaviour of others, we assess them based on the reasons we attribute to them. We are willing to reward /punish others if in our opinion what we observe is caused by them. Our tendency to do so decreases when we believe that what we observe was caused by external factors. The criterion of control corresponds to De Swaan's (1988) 'disability', understood as the incapacity to make a living through one's own effort. Welfare beneficiaries who are perceived as in control of their situation are blamed for it (Furaker and Blomsterberg 2003) and expected to change it. Previous studies show that attribution of responsibility for being in need appeared to be strongest predictor of deservingness of assistance (Applebaum, 2001; van Oorschot, 2000). Welfare recipients are considered deserving if they are motivated to improve their situation, but cannot cope with problems that are beyond their control. However, if the problem is not capability, but rather laziness, they are considered undeserving (e.g. Aaroe and Petersen, 2014; Petersen et al., 2014; Roosma, 2016).

The analysis of internet forums allowed to distinguish two main ways of assessing control: (a) controlling the cause of the need (CC) and (b) controlling the current situation $(C S)$. CC corresponds to the classic distinction of 'deserving' and 'undeserving': we are more likely to support poor people if we believe that the poverty is not due to their former behaviour or decision. Moreover a person in need may affect her current situation. We ask if she tries or does anything to improve her, and in this case, we assess CS.

In the case of the "Family 500+", the reason for being in need is having a childhence the control criterion applies to parents, children were completely omitted. The basic assumptions adopted by numerous participants of the analysed forums: (1) having a child is an expression of the parents' voluntary decision (cause control), (2) the material conditions of families with children are controllable by parents (situation control).

Cause control. Internet users do not deny that having children brings costs. What they raise is the argument that people should decide for children once they can afford to have them. 'if you have no money for children, you had to not have them' (Janek). Deciding for children with no means to provide for them characterises reckless people (vide the criterion of identity), who do not care about the consequences of their actions, and as a result they need to be helped (vide: reciprocity). 'They don't care about anything, they don't prevent, and then they expect support from the state' (wątpliwe). The opposite for them, according to some ODs participants, are the parents of a single child. Their situation is the result of 
well-thought-out decisions and, paradoxically just because of this (!) they are not entitled to the benefit.

Some discussions are devoted to parents for whom, according to Internet users, children represent main source of income. In this case the forums' posts contain pejorative terms such as 'baby-makers' (vide: identity), 'production of children'. To illustrate: 'in this country it is best not to work, produce children and count on help from social security' (piotr), 'baby-makers support $500+$, and taxpayers pay for it for years' (vide: reciprocity, identity). 'They deserve because they can make children' (Romek); People who decide to have another child because of the he program are particularly criticized. 'What a re.ard gives to another child because of getting $500+$ ? Only pathology.. not a responsible person!! They (the government-PM) can withdraw it at any time. Then who will support this child?' (ONA).

Situation control. Internet users expect parents to make decisions that result in satisfying the needs of their families; thus necessity of doing paid work is emphasized. Working appears in to be stressed also in relation to other criteria (vide: reciprocity); but in the case of control it has its specific meaning: it is related to abandoning job or not seeking employment. 'This program should not exist at all, because everyone should work for his own children and have as much as he can afford instead of reaching out for someone else's money' (xyz).

The above analysis allowed to indicate several relations between the CARIN criteria. ODs participants do not question the needs related to having a child; but stress parents' responsibility; thus, needs related to having a child are not a sufficient to deserve help (control \& need). (2) Underserving are those who decide for a child in order to get support 'the baby-makers' (control \& identity) or avoid doing paid work (control \& reciprocity), and people who do not raise their children to be valuable citizens (control \& (future) reciprocity).

\section{Attitude}

De Swaan (1988) distinguishes the "decent and embarrassed needy" who try to hide their misery, do not openly demand anything and accept help without asking for it. In contrast: others emphasize their misery and ostentatiously exaggerate. The deserving poor are conceived of as passive victims while undeserving openly demanding support "which is likely to be experienced as an aggressive or threatening act and at least always an uncomfortable one' (Erskine \& McIntosh, 2001).

The "non-passive victims" are in the opinion of some Internet users individuals demanding support from the state. 'A sense of entitlement', very pejorative description in Polish language, is understood as: a sense that the state or society owe someone's a living (vide: reciprocity). The attitudes are strongly stigmatized. It is not accepted to believe that not only it is possible to get money for nothing, but that one has a right to do so. 'Chancers and pathology take all possible benefits without doing anything. And they feel they deserve it' (SuenaJ).

ODs participant stress the potential effect of the benefit which in their opinion strengthens the demanding attitude among some parents and it is also likely to affect the children in the same way. It is assumed that family generates "cultural equipment" that promotes the negative attitudes of: idleness, greed, parasitism, sense of entitlement, sluggishness (vide: identity). Consequently, instead of contributing to the common good the future adults are 
expected to be welfare dependent (vide: reciprocity). 'A child must be brought up properly to work. These children will be raised in homes where they were taught that they deserve something for nothing. They will never take up work' (fff).

\section{Reciprocity}

In social psychology reciprocity refers to the sense of commitment to repay for what we receive from others. As a consequence I do not take from others if I cannot repay. However, reciprocity as criterion of deservingness assessment means that what is given must be somehow given back by the recipient. 'You will be not given while you do not add to the good of others.' People learned to monitor reciprocity and developed mechanisms for excluding those who do not follow this rule. In small groups, the inability to "repay" may be the reason why some people will not benefit from the help offered. In large groups it is the opposite; tendency to repay is much lower. Some ODs participants believe that some people use benefits without feeling pressure to repay to the society. The reciprocity criterion represents a script that defines needy families as people who are supported by the state, but do not contribute to the wealth of the nation due to welfare dependency.

There is a strong expectation among Internet users that the benefits recipients should repay with something positive. The expectation of reciprocity partly comes from the opinion that the benefits are paid from money taken from other members of society. For many ODs participants it represents loss and the sense of irreversible loss seems to reinforce the expectation of reciprocity.

Reciprocity can be seen in three time perspectives: the past (debt), the present (exchange) and the future (investment). In the debt perspective, we recognize that in the past a person did something good for us, the society, or the state. We usually refer it to the elderly, who contributed something in the past and today we are repaying the debt. The investment perspective relates to the future (Heuer and Zimmermann, 2020): expecting reciprocity in the future we agree to bear some costs today. In the exchange perspective; reciprocity amounts to the on-going exchange. We perceive someone as deserving because his activity contributes to the good of others and generates costs to the person.

Although at the Internet forums there are posts related to rewarding people who have cared for children in the past without state support (debt); much more attention is devoted to discussions about benefits for contemporary families with children. In the investment perspective individuals who benefit today are expected to repay in future. Because the repayment is expected to be in future the assessment of deservingness depends on faith, that today's children will at least reimburse for costs borne today. Internet users perceive the future contribution to the good of society as: doing paid work, contributing to the economic development, paying taxes, providing future pensions. But the contribution was also understood as ensuring the continuity of the Polish nation and increasing of Polish society. In this context, the role of parents with more than one child was emphasized. 'Large families put in effort to raise future taxpayers. Parents with one child only satisfy their instinct. Not only that, one child is not able to earn for the pension of the parents'. (iza).

An important topic of the online discussions is the role of the benefit itself in ensuring reciprocity. It was suggested that the allowance might cause children to be brought up by workavoiding parents. As a consequence children might learn to be welfare dependent. Thus, the benefit itself can reduce the chances that investing will bring benefits to the future. 'It is a pity 
that the increase in the number of children is most visible in families living on benefits. The younger generation will repeat their parents' scheme' (olo).

Also in investment perspective, it is often emphasized that benefits received by rich people will not contribute to the quality of future generations. Children in rich families have good development conditions (vide: needs) and " 500 +" does not aim to improve it. Hence, money spent on them are perceived as loss and not investment since it will not bring a return in future.

In exchange perspective and the attention of ODs participants is focused on parents. Contributing to the good of society is understood as: doing paid work, paying taxes, but also giving birth to children (which is important considering low fertility rate and aging society in Poland). The latter form of repay is questioned by some Internet users. They indicate that the benefit is used by families who already have children (and do not want to have another one) and thus are not likely to contribute to fertility rate. It is relatively frequent suggested that the allowance does not encourage to have children. And even if it does it is mainly in families which are unable to properly raise children (therefore, it cannot be expected that the investment in these children will pay off in the future).

In case of welfare benefits, breaking the quid pro quo rule can have two different forms. Firstly, an entitled person gives nothing in return. Secondly, person who contributes to the common good receives nothing in return. Many ODs posts applied reciprocity criterion to people who do work but they do receive benefits. It is emphasized not only that someone does nothing for the social good, but also that the allowance may push some people out of the labour market (vide: control). It is worth emphasizing that while some online discussion participants perceive mothers of adult children as deserving for support (while they used to give), there have been no suggestions that raising a child may be something that in itself deserves any reward. Having and looking after children is seen as a cost-generating activity and is therefore linked to a criterion of need rather than reciprocity. Paradoxically, the Internet discussions did not contain posts justifying deservingness for the benefit of mothers who were engaged in work before the birth of their children. The discussions concern only whether parents work now and not whether they worked before the child was born.

Many posts relate to families not entitled to the benefit (with one child or more dependent children, of which only one is younger than 18). It is indicated that earning a minimum wage parents of a single child earn more than the income threshold entitling them to claim the benefit. So, in the opinion of Internet users, they give something to the society (paid work, taxes) and receive nothing. Moreover, the same parents have difficulties making ends meet and investing in their children (vide: need), and they are in a relatively worse situation than those not working.

There is also a thread in the discussion around reciprocity: "I pay taxes, I owe it." Relatively often Internet users treat the benefit as a form of getting back of what in their opinion the state took from them. In this approach, the state reciprocates with citizens for what they do. These arguments help to justify deservingness of rich people even if they do not need money from benefits (reciprocity and need).

\section{Identity}

The identity criterion refers to closeness to potential beneficiaries. We are more willing to help people who are similar to us, with whom we share common values and beliefs, as well as those who are somewhere close. It partly explains why immigrants are often perceived as the least deserving (Nielsen et al., 2020; van Oorschot, 2006, 2008). 
In their recent study Heuer and Zimmerman (2020) found that respondents emphasize identity (as well as the need and social investment) as the main deservingness criteria that are applied with regards to families. People who stereotypically violate the dominant social norms, for example single mothers, are more likely to be found undeserving (Herke, 2019).

The identity criterion strongly fits into 'them' versus 'us' logic. People who are perceived as different constitute 'them' in regards to the notion of social citizenship. De Swaan (1988) relates identity to kinship (e.g.: mutual duty of support for parents and children) and residence (the place of residence indicates that helping those in need falls on the shoulders of people living in the same area, for example, the First Law of the Poor, forced each local community to support the poor living in the same area). My analysis of internet forums has revealed at least two mental borders separating 'us' from 'them':

- Civic attitudes and behaviour:-we are good citizens, work, pay taxes, we are honest, contribute to the good of the society. They are: 'lazy-bones', 'scammers', 'deviants', 'parasites prone to excessive consumption'. Terms that are used to deprecate those receiving benefits are: 'pathology', 'loafers', 'alcoholics', 'sots', etc. A typical example of the phrase: 'Pathology buys cars for 500+' (rak). In this case, the criterion of identity is largely related to reciprocity and needs (e.g.: the rich people who cheat in order to get the benefit).

- Parental attitudes and behaviour; we are responsible, rationally plan offspring, assess our abilities to meet the needs of a child, care for our children. They are unreasonable (they decide to have children they can't afford) or oriented to get money from child benefits; the number of children is crucial for them-while it affects the value of the benefit. They are irresponsible and have many children they do not care for. 'The pathology of children-makers who have never worked anywhere can get several thousand' (pingwiniarz). In this case, the "identity" criterion remains in close relation to the control and reciprocity criteria.

\section{Need}

Satisfying human needs provides one of the strongest reasons for implementing social policy. The criterion of need, as defined by van Oorschot (2006) means that the greater the level of person's need, the more we find the person deserving. It means that the more difficulty people have meeting their needs the more we are willing to help them (van Oorschot, 2000).

Any person who assesses deservingness through the scale of needs put herself in the role of expert. She authoritatively determines what others need and to what extent. The criterion of need largely corresponds to the concept of normative need described by Bradshaw (1972/2013). A normative need is one that is indicated by experts who determine what needs people have and what is the minimum level of the needs' satisfaction (Bradshaw, 2013). So does every person.

The study reveals that the need criterion has been discussed by ODs participants in relation to entitlement. Three groups of people were distinguished: entitled-and-deserving, entitled-but-undeserving, unentitled-but-deserving.

Internet users considered the benefit definitely helps to meet the basic needs (e.g. food, clothing). Thus the entitled-deserving are mainly: poor, single parents and families with sick children; and the deservingness is varies with age and number of children. Additionally 
people who are able to meet their basic needs might be considered as deserving i.e.: parents, who in order to meet the needs of their children, give up meeting their own needs, and parents who have not enough money to satisfy higher-level needs (vacation, swimming lessons) or investment needs (foreign language lessons, development of interests). '(...) Two of my friends with 3 and 4 children regularly go on vacation for the last two years, just in Poland because they prefer it, but with poor earnings half of the annual 500 plus for three children is already a very good vacation' (meth).

A relative element also appears in the analysed posts. Parents bear the costs of having a child, which puts them at a disadvantage compared to childless people. The latter, by many ODs participant are described as 'parasites' i.e. feeding on the effort of people raising children (vide: reciprocity). In addition to arguments related to the size of needs, there are also those that indicate obstacles to work for pay. Deservingness grows not only because of the size of the need, but also because of the limited possibilities of satisfying them due to reduced earning potential.

The online discussions concern people who are entitled to benefit, but should not receive it: entitled but undeserving. (1) In this group are rich families because the needs of the their members are met and as a result the money received from the state is expected to be used for satisfying desires not needs. Moreover, the benefits paid to the rich are financed by taxes paid by the poor who are unable to meet the needs of their families (vide: reciprocity). (2) People who act dishonestly in order to receive benefits or not pay taxes. In this case the ODs participants bracket together single mothers who are in informal relationships and people who avoid paying taxes. Women cheat (vide: identity) and their goal is to extort social security benefits, although in reality the material situation of their families is relatively good. Informally employed people as well as entrepreneurs and farmers who hide their income not only do not need support but do not themselves contribute to the good of others (vide: reciprocity) and at the same time they belong to the group 'they-thescammers' (vide: identity).

Most of the comments were related to unmet income criterion; unentitled but deserving people are those whose needs were unsatisfied but they were not entitled to benefits. This group includes working poor whose income is low but higher than the minimum specified by social law. Moreover ODs participants emphasized that it is because of doing paid work, the needs of some families are greater (childcare, travel to work, etc.). In contrast to those who do not work and are entitled the working poor pay taxes, but are not supported (vide: reciprocity). Not entitled but deserving are also families in which: (1) disposable income is less than officially registered by welfare institution (e.g. mothers who are not divorced but being the only breadwinner and raising a child alone with no material support from a partner), (2) there are costs associated with children, but the state does not take these children into account (young adults dependent on parents). Despite the having the obvious needs, the family is not entitled to the benefit for both: an adult child and a younger child.

ODs participants discussed deservingness of families who could contribute to achieving the objectives of the program (increasing the number of children born). It is pointed out that some parents of a single child postpone having more children due to financial reasons, and they will not decide to have another child because they are not entitled to the benefit. This observation leads to question for future studies: how does the perceived purpose of the programme affect the assessment of deservingness?

An important thread revealed by analysis was the decision: whose needs, parents or children, should be met? Unlike the standard thinking about the criterion of needs this discussion focused more on 'type' and 'quality' of needs rather than their size. While most Internet users were positive about meeting the needs of children: the basic ones, 
human capital investing related, leisure, vactation etc.; there were many reservations about meeting the needs of parents. Especially those related to the possession of material goods (car, TV-set), unnecessary services (hairdresser) and excessive consumption (of alcohol and cigarettes). This observation prompted me to propose a new criterion for assessing deservingness: adequacy.

\section{CARIN or CARINA? The Criterion of Adequacy}

A large part of the discussions on Internet was devoted to the issue how the money from benefits was used by entitled families. People who spent money in an appropriate, adequate manner were considered as deserving. Although related to the criterion of need and identity, adequacy remains significantly different from them. The Internet users did not question the fact that children/families with children have extensive needs. However they strongly opposed to spending money for satisfying the wants of parents. According to the criterion of adequacy, people do not deserve support when we assume that money is allocated to something that is unnecessary (e.g. TV, car), excessive (e.g. cosmetics) or even harmful (e.g. alcohol). Adequacy means that the more we believe that a person makes good use out of the received benefit, the more deserving she is. People put satisfying objective needs ahead of satisfying (subjective by nature, frivolous) desires. "Priority of needs" means that: needs should always take absolute precedence priority over satisfying people's mere desires (Goodin, 1988).

The importance of the adequacy criterion is greater for cash benefits than services. This is due to the nature of money, a medium of exchange, it can be used for many different purposes. However, it does not mean that support in the form of services cannot be evaluated with use of adequacy criterion. For example: training for the unemployed who participate in it only in order to avoid losing the right to unemployment benefit; they are likely to have low score on the scale of adequacy.

The low level of adequacy often leads to the view that it is necessary to introduce social control of the use of benefits or to change their form, from cash to material or service. Once we consider that the benefit granted by state is likely to be misused and/ or because it is believed that it would not result in positive changes, we do not find the beneficiary deserving.

\section{Discussion and Summary}

1. In 2019, Laenen, Rossetti and van Oorschot published an article indicating the need for qualitative research in studies of deservingness. Referring to the popular criteria: control, attitude, reciprocity, need and identity (CARIN) the authors pointed out that in studies dominated by quantitative analyses, one cannot find answers to two important questions: 'Do people really use (all) these criteria (maybe they also use others)?' and: "How exactly do people understand these criteria?'. Finding answers to these questions was the first goal of this article. This study of Internet discussions on "Family 500 +" programme in Poland shows how people understand criteria of deservingness, and it also provides a proposal of a new criterion and displays the relations between the criteria. 
- Control -refers only to parents (and not children) and is understood by respondents in two ways: as a control of cause and as a control of current situation. The perceived deservingness for the ' 500 +' allowance is lower; when the respondents find the beneficiaries contributed to the need arise (control of the cause); both intentionally (especially: in order to get the welfare benefits) or because of being reckless. Similarly; the beneficiaries do not deserve to be supported if they do not themselves take measures to improve their current situation (control of situation). Contrary; the deserving people consciously plan their offspring and decide to have children when they can afford them (control of cause). The deserving are also parents who, despite working, are not able to meet the needs of their family (control of situation).

- Attitude - as in de Swaan's writings (1988) ODs participants are not willing to help people who openly demand support. The attitudes that make people underserving: idleness, parasitism, and especially: 'a sense of entitlement' - a sense that the state, owe someone's living.

Internet users also emphasized that due to ' $500+$ ' benefit the negative attitudes are likely to be widespread, strengthen and inherited. Thus, the benefit itself contributes to shaping attitudes, which in turn lower deservingness.

- Reciprocity was analysed in three perspectives: debt, investment and exchange. Internet users made distinctions regarding deservingness based on the contribution of parents and children. Parents deserve support because (exchange perspective) they (decide to) have children (survival of the Polish nation, more employees/ taxpayers in the future) and bear the costs of having children while the whole society benefits. What reduces parents' deservingness is: not working, not paying taxes, improper child rising. A special case are parents who already have children and do not plan to have more. In this case, it is assumed that subject of exchange is the birth of a child and not raising the children.

Children deserve support because (investment perspective) they are expected to repay in future; the $500+$ benefit represents an investment. They are not deserving because of: inheritance of undesirable attitudes and possibility of future emigration from Poland. Many arguments amount to the idea that money spent today is wasted and will not bring benefits in the future, because families misuse it. Somewhat differently, the idea of misuse of the $500+$ allowance applies to rich families. In their case, the money from the allowance is perceived as wasted because it is not expected to increase the level of investment in children.

- Identity-Internet users distinguished deserving "us" from undeserving 'them' by highlighting the differences in two groups of attitudes and behaviours, i.e.: civic and parental. People who deserve to be supported are like 'us' are honest and responsible, they work, pay taxes, contribute to the good of all (civic), responsibly plan offspring and care for their children (parental). "The others" are not deserving because they are dishonest, irresponsible, lazy, dependent on support (civic); and they raise their children improperly (parental).

- Needs-families allocating money to meet their basic needs are perceived as deserving. Moreover, children's needs are prioritised with parents' needs perceived as secondary. Families were found undeserving when the benefit was only a "supplement" to high incomes of the rich people and dishonest ones (e.g. cheating single parents). The analysis of the criterion of needs turned out to be particularly fruitful in terms of identifying people who deserve an allowance but are not entitled to it (e.g. working poor). 
2. The concept of deservingness is inextricably linked to common, transmitted through everyday discourse, perceptions of attitudes and behaviour of the welfare beneficiaries. The study made me to propose a new criterion of deservingness: adequacy. It has been found that deservingness is primarily determined by how, in the respondent's view, the beneficiary uses the benefit. A person does not deserve support, if she allocates the benefit for: (1) satisfying frivolous desires instead of "real" needs, (2) spending the money contrary to its purpose (defined by the forum participants or the state), (3) satisfying the needs of people (parents) other than those to whom the benefit is addressed (children). The recognised inadequate use of benefits leads to recommendations of changes of the form of support from cash to service or introduction of a control of its use.

3. Numerous studies empirically verified the CARIN model (e.g. Kootstra, 2017; Laenen et al., 2019; Nielsen et al., 2020). First van Oorschot (2000), and subsequently other authors (e.g. Applebaum, 2001) suggested that control, reciprocity and identity play crucial role among the model criteria. However, recent studies indicate that the perception of deservingness differs depending both on the characteristics of the respondent and potential beneficiaries of social benefits (Jeene et al., 2013; Meuleman et al., 2020; Gielens et al., 2019). Consequnetly, Heuer and Zimmerman (2020) suggest that one criterion may be used by respondents to justify their assessment of deservingness, both high and low.

The nature of deservingness attitudes appeared to be surprisingly complex. Rather than indicating whom Poles consider the most / least deserving, this paper assessed shows the social perception of the criteria and the relationships between them. Nielsen et al. (2020) stress that the literature usually treats the criteria of deservingness as separate dimensions in which potential beneficiaries (groups of beneficiaries) can achieve higher or lower results. The paper recognized the impurity of all deservingness criteria. It seems to be justified to suggest that none of the criteria tested is 'clear' and treating the criteria separately can give an incomplete and biased picture. The analysis of online discussions indicated that multiple criteria were used simultaneously, e.g. identity and reciprocity, needs and attitude. Many arguments referred to two or three criteria simultaneously. The study shows that the deservingness of families/parents/children to some extent depends on which subgroup the respondents have considered (Roosma \& Jeene, 2017). People seem to avoid ambiguity rather than try to perceive group diversity. The respondents seem to have judged the deservingness of everyone in the group (parents with children) on the basis of their perception of a specific subgroup. The choice of this subgroup turned out to be decisive, however it requires further studies.

4. The internet forums were used in social studies before, but according to the author's knowledge it is the first time they were used to study welfare attitudes and deservingness perception. The great benefit of using the text data from the online debates is anonymity of the users. Anonymous internet forum participants have their opinions and want to share them even the unpopular and politically incorrect ones. Thus it significantly eliminates the typical problems of surveys, interviews and focus groups. The limitations of the Internet forums studies are: deindividuation and lack of representativeness. While the Internet forums do not provide the statistical representativeness of social surveys their role is rather complementary than substitutional. The limitation is also the fact that only people who have access to the Internet can participate in the study-however the population of Internet users is growing and conducting my study was possible thanks to 
the widespread familiarity with the "Family 500+" program in Polish society, as well as the wide discussion that the program sparked among Poles. The study also showed that most forum posts serve to express disapproval of the program. It seems that program supporters are relatively less frequently represented on internet forums, or have no need to express their opinions.

5. Although deservingness of children is usually high-rated the analysis of concrete and not abstract benefit revealed something that in the previous studies remained unnoticed. The aim of ' $500+$ ' ' is to improve the objective wellbeing of children by investing in human capital and preventing poverty of families. However, the vast majority of posts on Internet forums refer to deservingness of parents, not children. This is particularly evident in relation to the criteria of control and reciprocity. Similarly when deservingness criteria are applied to children, the way parents are perceived remains important. This is the case, for example, with criteria of attitude (children raised by demanding parents, are expected to be demanding citizens in the future) or reciprocity (parents living on benefits bring up children who will not learn how to work and pay taxes).

6. In the analysed period half of all families with children in Poland received ' $500+$ ' allowance. And yet many online discussions are full of prejudices and stereotypes and are focused on socially marginalised groups. Emphasizing the 'negative' otherness of the program can also be an expression of the scapegoat strategy. Social psychologists suggest that a frustrated person feels a strong tendency to face the cause of her frustration. However, individuals may find that the cause of frustration is too powerful or unspecified. This can be the case with state policy. A person may recognize that there is no way to influence what policymakers do, which is why she is looking for a "scapegoat" upon whom she releases her frustration (Aronson, 2012).

The search for a scapegoat can also be an expression of negative feelings such as jealousy and envy; which revealed might prove that the person herself has negative, socially undesirable traits. Thus, when assessing deservingness, individuals present the beneficiaries in a very negative light and stress the destructive consequences of introducing the benefit: state debt, economic slowdown, abandonment of investment, etc. Is the jealousy hypothesis correct, this has extremely important consequences for welfare attitude studies. A person uses CARINA criteria to justify her original attitudes towards state policy. The perceived deservingness for assistance serves as a rhetorical device used to protect the hidden views. A similar process may occur when protecting persons' own interest. People can intentionally use the deservingness criteria in order to defend their own interest. Resolving these uncertainties requires further investigation.

7. When answering the question: who should be supported by state and society?- people use various criteria not always related to deservingness. Kagan argued (2012): "Of course, few if any of us believe that desert is the only thing that matters morally, so it is possible that in various cases giving people what they deserve might still leave an outcome worse overall." Due to the extensiveness of this topic, it has not been developed in this article, but it is worth noting that references to (variously) perceived justice, potential socio-economic consequences and what I call 'institutional justifications' (e.g. deserving because he is entitled) have often appeared on forums. Debates about welfare state beneficiaries' (un) deservingness involve divergent and often competing moral stances about whose needs should or should not be satisfied with public help. 
8. Deservingness also turn out to be often assessed ex ante on the basis of the potential impact of the benefit on behaviour and attitudes, and not ex post on the basis of what was observed. While the online forums participants have not addressed the issue of deservingness of women who used to work before becoming a parent (ex post); they conditioned deservingness on untestable cause-and-effect relationship about what, in their opinion, is going to happened. This is particularly evident in the context of the criteria of: attitudes and reciprocity. Sceptics argue that in the long run the benefits undermine the social fabric by leaving todays and future families vulnerable. It is suggested that the allowance deepens and spreads state of entitlement attitudes among parents and discourage them from doing paid work. And, moreover, through "cultural equipment" it is expected to negatively affect the attitudes of future generations of Poles (inheritance of attitudes). This issue also requires further studies.

\section{Appendix 1}

List of the Internet debates used in the study.

1. http://extra.natemat.pl/krolestwo-500plus-90procent-pobiera-swiadczenie

2. http://www.polityka.pl/forum/1298070, coraz-wiecej-kobiet-rezygnuje-z-pracy-toefekt-programu-500.thread

3. http://www.tomaszow.lub.pl/forum/viewtopic.php?f=25\&t=118695\&start=120

4. https://bezprawnik.p1/500-plus/

5. https://demotywatory.pl/4804274/O-tym-dlaczego-program-500+-jest-szkodliwywypowiedziala-sie

6. https://demotywatory.pl/4877273\#comments

7. https://dziecko.trojmiasto.pl/Hejt-na-rodziny-korzystajace-z-500-plus-Skad-sie-bierzen117197.html

8. https://dziennikpolski24.pl/1000-plus-zamiast-500-plus-a-kto-to-sfinansuje-biznesboi-sie-ze-spelnienie-obietnic-wyborczych-i-zasilki-pograza-gospodarke/ar/c1-14509 015

9. https://epoznan.pl/komunikacja-news-91025-Sondaz_na_temat_programu_500+_ odebrac_swiadczenie_najbogatszym,_przyznac_wszystkim_samotnym_rodzicom_i_ uzaleznic_wyplate_od_szczepienia_dziecka

10. https://epoznan.pl/sport-news-88145-Minister_Rafalska_o_500_plus_trzeba_bedzie_ sie_zastanowic_nad_kryterium_dochodowym

11. https://f.kafeteria.pl/temat-6455186-do-krytykantek-500-plus/

12. https://f.kafeteria.pl/temat-6527795-500-plus-patologia/

13. https://f.kafeteria.pl/temat-6667732-krew-mnie-zalewa-na-to-500-plus/

14. https://f.kafeteria.pl/temat-7608614-kiedy-zabiora-500-plus/

15. https://finanse.wp.pl/program-500-nie-zachecil-kobiet-do-rodzenia-polki-niewzruszo ne-polityka-prorodzinna-rzadu-6165769767339649a

16. https://forsal.pl/artykuly/1004429,500-plus-zacheca-do-rodzenia-po-trzydziestcebedzie-wiecej-dzieci.html

17. https://forum.gazeta.pl/forum/w,567,164877728,164877728,500_do_zwrotu.html

18. https://forum.gazeta.pl/forum/w,567,165696987,165696987,Efekty_500_.html

19. https://forum.interia.pl/wielu-krytykuje-program-500-tematy,dId,2984209 
20. https://gazetakrakowska.pl/500-plus-na-dziecko-zastapi-1000-plus-jest-to-bardzomozliwe-i-calkiem-realne/ar/13396397

21. https://gazetakrakowska.pl/eksperci-500-plus-jeszcze-nie-zacheca-do-rodzenia-dzieci/ $\operatorname{ar} / 11856978$

22. https://gazetawroclawska.pl/na-dolnym-slasku-juz-zabieraja-500-plus-sprawdz-komu/ ar/10624309

23. https://gospodarka.dziennik.pl/finanse/artykuly/595174,500-plus-skutki-ubocznepolacy-przestaja-ufac.html

24. https://pomorska.pl/co-dalej-z-programem-500-plus-szykuja-sie-spore-zmiany-tojednak-nie-koniec-programow-tego-typu/ar/c1-14764690

25. https://pomorska.pl/zmiany-w-programie-500-plus-600-plus-dla-pracujacych-i-bonyzamiast-pieniedzy-sa-pomysly-i-decyzje/ar/c3-14678843

26. https://poranny.pl/pracowalam-przy-500-poznajcie-prawde-list/ar/10062186

27. https://praca.gazetaprawna.pl/artykuly/1020586,500-zl-na-dziecko-kto-nie-bierzepieniedzy-z-500.html

28. https://praca.gazetaprawna.pl/artykuly/1097962,w-2019-r-rzad-poszerzy-program-500. html

29. https://program500plus.org.pl/forum/czy-500-plus-jest-dobre/

30. https://wiadomosci.dziennik.pl/opinie/artykuly/509846,list-matki-czworki-dzieci-wsprogramu-500-zl-na-dziecko.html

31. https://wiadomosci.dziennik.pl/opinie/artykuly/518591,sergiusz-prokurat-program500-plus-to-powod-do-wstydu.html

32. https://wiadomosci.wp.pl/opozycja-zglupiala-przez-500-nie-wiedza-jak-sie-zachowac$6109098672535681 \mathrm{a}$

33. https://wizaz.pl/forum/showthread.php?t=836804

34. https://www.bankier.pl/wiadomosc/Bugaj-Rodzina-500-plus-nie-zrujnuje-budzetupanstwa-7473512.html

35. https://www.dziennikwschodni.pl/forum/region/lubelskie/500-w-lubelskiem-dlacz ego-nie-ma-znacznego-wzrostu-urodzin-wicewojewoda-odpowiada,t, 174374.html

36. https://www.familie.pl/Forum-3-28/m1303572-1,Na-co-wydajemy-500.html

37. https://www.gry-online.pl/S043.asp?ID=14448638

38. https://www.money.pl/gospodarka/wiadomosci/artykul/500-program-500-oszczednos ci-polakow, 192,0,2270912.html

39. https://www.nowiny.pl/153877-co-sadzisz-o-programie-500-plus-sonda.html

40. https://www.papilot.p1/lifestyle/bez-tabu/36538/duzo-dzieci-w-mlodym-wieku

41. https://www.portalsamorzadowy.pl/forum/78925_0.html

42. https://www.rodzice.pl/500-na-pierwsze-dziecko-zmiany-od-sierpnia-2017/

43. https://www.youtube.com/watch? $\mathrm{v}=\mathrm{k} 8 \mathrm{oDx} 0-\mathrm{GWKw}$

44. https://wyborcza.pl/7,155287,24845268,kto-zasluguje-na-500-pracowici-i-ambitnikontra-ciemny.html

Funding Narodowe Centrum Nauki (2018/31/B/HS5/01707)

Open Access This article is licensed under a Creative Commons Attribution 4.0 International License, which permits use, sharing, adaptation, distribution and reproduction in any medium or format, as long as you give appropriate credit to the original author(s) and the source, provide a link to the Creative Commons licence, and indicate if changes were made. The images or other third party material in this article 
are included in the article's Creative Commons licence, unless indicated otherwise in a credit line to the material. If material is not included in the article's Creative Commons licence and your intended use is not permitted by statutory regulation or exceeds the permitted use, you will need to obtain permission directly from the copyright holder. To view a copy of this licence, visit http://creativecommons.org/licenses/by/4.0/.

\section{References}

Aaroe, L., \& Petersen, M. B. (2014). Crowding out culture: Scandinavians and Americans agree on social welfare in the face of deservingness cues. Journal of Politics, 76(3), 684-697. https://doi.org/10.1017/ S002238161400019X.

Alesina, A., \& Angeletos, G.-M. (2005). Fairness and redistribution. American Economic Review, 95(4), 960-980. https://doi.org/10.1257/aer.103.1.554

Alesina, A., Glaeser, E. \& Sacerdote, B. (2001) Why Doesn't the United States Have a European-Style Welfare System?. NBER working paper, (8524). https://doi.org/10.1017/CBO9781107415324.004.

Applebaum, L. D. (2001). The influence of perceived deservingness on policy decisions regarding aid to the poor. Political Psychology, 22(3), 419-442. https://doi.org/10.1111/0162-895x.00248

Arkin, R. M., Appelman, A. J., \& Burger, J. M. (1980). Social anxiety, self-presentation, and the selfserving bias in causal attribution. Journal of Personality and Social Psychology, 38(1), 23-35. https://doi.org/10.1037/0022-3514.38.1.23

Aronson, E. (2012). The Social Animal. 11th edn. Worth Publishers. https://doi.org/10.1016/S01406736(53)91970-9.

Barratt, M. J. (2011). Discussing illicit drugs in public internet forums: Visibility, stigma, and pseudonymity, C and T 2011 - 5th International Conference on Communities and Technologies, Conference Proceedings, pp. 159-168. https://doi.org/10.1145/2103354.2103376.

Beeder, L. \& Samplaski, M. K. (2019) Analysis of online discussion boards for male infertility. Andrologia, 51(11). https://doi.org/10.1111/and.13422.

Bradshaw, J. (2013) A taxonomy of social need. In Bradshaw, J. R. et al. (eds) Jonathan Bradshaw on Social Policy. Selected Writings 1972-2011. University of York, pp. 1-12.

CBOS (2016) 'Program , Rodzina 500 plus " jako element systemu wspierania rodzin i dzietności', Komunikat z badań, (25).

CBOS (2019a) 'Korzystanie z Internetu', Komunikat z badań, (95).

de Swaan, A. (1988). In Care of the State. Oxford University Press.

Erskine, A. and McIntosh, I. (2001) 'Why begging offends: historical perspectives and continuities', in Hartley, D. (ed.) Begging questions. Street-level economic activity and social policy failure. Bristol: The Policy Press, pp. 27-42.

Furaker, B. and Blomsterberg, M. (2003). Attitudes towards the unemployed. An analysis of Swedish survey data. International Journal of Social Welfare, 12(3), 193-203. https://doi.org/10.1111/14682397.t01-1-00005

Gielens, E., Roosma, F., \& Achterberg, P. (2019). Deservingness in the eye of the beholder: A vignette study on the moderating role of cultural profiles in supporting activation policies. International Journal of Social Welfare, 28(4), 442-453. https://doi.org/10.1111/ijsw.12392.

Goodin, R. E. (1988). Reasons for Welfare. The Political Theory of the Welfare State. Princeton University Press.

Greer, I. (2016). Welfare reform, precarity and the re-commodification of labour. Work, Employment \& Society, 30(1), 162-173. https://doi.org/10.1177/0950017015572578

Hausner, H., Hajak, G., \& Spieß1, H. (2008). Gender differences in help-seeking behavior on two internet forums for individuals with self-reported depression. Gender Medicine, 5(2), 181-185. https:// doi.org/10.1016/j.genm.2008.05.008

Herke, B. (2019). 'Investigating the Welfare Deservingness of Single Mothers: Public Image and Deservingness Perceptions in Hungary.' SPSW Working Paper CeSo/SPSW/.

Heuer, J.- O., Zimmermann, K. . (2020). Unravelling deservingness: Which criteria do people use to judge the relative deservingness of welfare target groups? A vignette-based focus group study. Journal of European Social Policy, 30(4), 389-403.

Holtz, P., Kronberger, N., \& Wagner, W. (2012). Analyzing internet forums a practical guide. Journal of Media Psychology, 24(2), 55-66. https://doi.org/10.1027/1864-1105/a000062

Hughes, R. (1998). Considering the vignette technique and its application to a study of drug injecting and HIV risk and safer behaviour. Sociology of Health and Illness, 20(3), 381-400. https://doi.org/ $10.1111 / 1467-9566.00107$ 
Hwang, K. O. et al. (2007). Quality of weight loss advice on internet forums. American Journal of Medicine, 120(7), 604-609. https://doi.org/10.1016/j.amjmed.2007.04.017.

Im, E.-O., \& Chee, W. (2006). An online forum as a qualitative research method. Nursing Research, 55(4), 267-273. https://doi.org/10.1097/00006199-200607000-00007

Jeene, M., \& Van Oorschot, W. (2014). The relative deservingness of the unemployed in the eyes of the European public. European Values Studies, 15, 95-115. https://doi.org/10.1163/9789004261662_ 006

Jeene, M., van Oorschot, W., \& Uunk, W. (2013). Popular criteria for the welfare deservingness of disability pensioners: The influence of structural and cultural factors. Social Indicators Research, 110(3), 1103-1117. https://doi.org/10.1007/s11205-011-9974-7

Jordan, C. J., \& Caldwell-Harris, C. L. (2012). Understanding differences in neurotypical and autism spectrum special interests through internet forums. Intellectual and Developmental Disabilities, 50(5), 391-402. https://doi.org/10.1352/1934-9556-50.5.391

Kagan, S. (2012). The Geometry of Desert. Oxford University Press.

Kalton, G., \& Schuman, H. (1982). The effect of the question on survey responses: A review. Journal of the Royal Statistical Society. Series A (General), 145(1), 42-73. https://doi.org/10.2307/2981421

Kootstra, A. (2017) The New Undeserving Poor. An Experimental Study of Welfare Chauvinism in Britain and the Netherlands. Unpublished PhD thesis, University of Manchester.

Laenen, T., Rossetti, F., \& van Oorschot, W. (2019). Why deservingness theory needs qualitative research: Comparing focus group discussions on social welfare in three welfare regimes. International Journal of Comparative Sociology, 60(3), 190-216. https://doi.org/10.1177/0020715219837745

Lahusen, C., Grasso, M. T. \& Ruzza, C. (2018) Solidarity in Europe: Citizens' responses in times of crisis. Springer International Publishing.

Larsen, C. A. (2008). The institutional logic of welfare attitudes: How welfare regimes influence public support. Comparative Political Studies, 41(2), 145-168. https://doi.org/10.1177/0010414006295234

McSwain, S., Lester, D., \& Gunn, J. F. (2012). Warning signs for suicide in internet forums. Psychological Reports, 111(1), 186-188. https://doi.org/10.2466/12.13.PR0.111.4.186-188

Meuleman, B., Roosma, F., \& Abts, K. (2020). Welfare deservingness opinions from heuristic to measurable concept: The CARIN deservingness principles scale. Social Science Research, 85, 102352. https:// doi.org/10.1016/j.ssresearch.2019.102352.

Michoń, P. (2020 - under review) ' The "Family 500+" as Social Investment Aimed at Increasing the Number of Children in Poland-Internet Forums Discourse Analysis', Studia Demograficzne.

MRPiPS (2019) Rodzina 500+. Już trzy lata jesteśmy z wami. Warszawa: MRPiPS.

Nielsen, M. H., Frederiksen, M., \& Larsen, C. A. (2020). Deservingness put into practice: Constructing the (un)deservingness of migrants in four European countries. British Journal of Sociology, 71(1), 112126. https://doi.org/10.1111/1468-4446.12721.

Olesen, T. (2019). Deservingness and political preference in opinions on distant suffering. Current Sociology, 67(3), 456-473. https://doi.org/10.1177/0011392118807536

Petersen, M. B. (2011) 'Social Welfare as Small-Scale Help: On the Evolved Roots of the Deservingness Heuristic', American Journal of Political Science, (July), pp. 1-47. https://doi.org/10.1111/j.15405907.2011.00545.x.

Petersen, M. B., et al. (2014). Social welfare and the psychology of food sharing: Short-term hunger increases support for social welfare. Political Psychology, 35(6), 757-773. https://doi.org/10.1111/ pops. 12062.

Reeskens, T., \& van der Meer, T. (2019). The inevitable deservingness gap: A study into the insurmountable immigrant penalty in perceived welfare deservingness. Journal of European Social Policy, 29(2), 166-181. https://doi.org/10.1177/0958928718768335

Reicher, S. D., Spears, R., \& Postmes, T. (1995). A social identity model of deindividuation phenomena. European Review of Social Psychology, 6(1), 161-198. https://doi.org/10.1080/14792779443000049

Ring, D. M., \& Oei, S.-Y. (2016). The tax lives of Uber drivers: Evidence from online forums. Columbia Journal of Tax Law, 8(1), 56-112.

Roosma, F. (2016), A Multidimensional Perspective on the Social Legitimacy of Welfare States in Europe. Ridderprint.

Roosma, F., Jeene, M. (2017), The Deservingness Logic Applied to Public Opinions Concerning Work Obligations for Benefit Claimants. In W. van Oorschot, F. Roosma, B. Meuleman, T. Reeskens (Eds.), The social legitimacy of targeted welfare: Attitudes on welfare deservingness (pp. 189-206). Edward Elgar Publishing

Rothstein, B. (1998). Just institutions matter. The moral and political logic of the universal welfare state. Cambridge University Press. 
Seale, C., et al. (2010). Interviews and internet forums: A comparison of two sources of qualitative data. Qualitative Health Research, 20(5), 595-606. https://doi.org/10.1177/1049732309354094.

Shanks, A. et al. (2014) 'Making sense of patients ' internet forums :', British Journal of General Practice, (March), pp. 178-180. https://doi.org/10.3399/bjgp14X677671.British.

Soussan, C., \& Kjellgren, A. (2015). "Chasing the high" - Experiences of ethylphenidate as described on international internet forums. Substance Abuse: Research and Treatment, 9, 9-16. https://doi.org/10. 4137/SART.S22495.

Tumarkin, R., \& Whitelaw, R. F. (2001). News or noise? Internet postings and stock prices. Financial Analysts Journal, 57(3), 41-51. https://doi.org/10.2469/faj.v57.n3.2449.

van Oorschot, W. (2000). Who should get what, and why? On deservingness criteria and the conditionality of solidarity among the public. Policy \& Politics, 28(1), 33-48.

van Oorschot, W. (2006). Making the difference in social Europe: Deservingness perceptions among citizens of European welfare states. Journal of European Social Policy, 16(1), 23-42. https://doi.org/10. $1177 / 0958928706059829$

van Oorschot, W. J. H. (2008). Solidarity towards immigrants in European welfare states. International Journal of Social Welfare, 17(1), 3-14.

Weiner, B. (1986). An Attributional Theory of Motivation and Emotion. Springer, US. https://doi.org/10. 1007/978-1-4612-4948-1

Publisher's Note Springer Nature remains neutral with regard to jurisdictional claims in published maps and institutional affiliations. 